Research article

\title{
CHANGES IN THYROID HORMONES LEVELS AND METABOLISM IN DAIRY COWS AROUND CALVING
}

\author{
FIORE Enrico ${ }^{1}$, GIAMBELLUCA Sonia ${ }^{1}$, MORGANTE Massimo, \\ PICCIONE Giuseppe ${ }^{2 *}$, VAZZANA Irene ${ }^{3}$, CONTIERO Barbara ${ }^{1}$, \\ OREFICE Tiziana ${ }^{3}$, ARFUSO Francesca ${ }^{2}$, GIANESELLA Matteo ${ }^{1}$
}

\begin{abstract}
${ }^{1}$ Department of Animal Medicine, Productions and Health (MAPS), University of Padua, Viale dell'Università 16 - 35020, Padua (PD), Italy; ${ }^{2}$ Department of Veterinary Sciences, University of Messina, Polo Universitario dell'Annunziata, 98168, Messina (ME), Italy; ${ }^{3}$ Experimental Zooprophylactic Institute of Sicily, Via Gino Marinuzzi 3, 90100, Palermo (PA), Italy
\end{abstract}

(Received 22 November 2016, Accepted 24 April 2017)

The hormonal activity of the thyroid gland has an important role in ruminants for the modulation of metabolic variables. In this study changes in thyroid hormones and biochemical parameters in dairy cows around calving were evaluated and the critical thyroid hormones thresholds for predicting the risk of ketosis were estimated. Blood samples were collected from 82 dairy cows at $5 \pm 3$ days pre-partum and $5 \pm 3$ days postpartum. Serum values of triiodothyronine (T3), thyroxine (T4), thyroid-stimulating hormone (TSH), non-esterified fatty acids (NEFA), $\beta$-hydroxybutyrate (BHB), insulin, glucose, $\mathrm{Ca}, \mathrm{Cl}, \mathrm{Mg}, \mathrm{P}, \mathrm{K}, \mathrm{Na}$, aspartate transaminase (AST), alanine transaminase (ALT) and urea were evaluated. Significant decrease in the levels of T3, T4 and TSH was found in the postpartum period. The values of T3 and T4 were negatively correlated with NEFA and BHB levels, and TSH values were negatively correlated with NEFA. A critical T3 threshold was found by means of ROC analysis for predicting the risk of ketosis. T3 values $<1.23 \mathrm{nmol} / \mathrm{L}$ were associated with $\mathrm{BHB}>1.10 \mathrm{mmol} / \mathrm{L}$ in postpartum, which represents the $\mathrm{BHB}$ threshold commonly used as the indicator of hyperketonaemia.

The results confirm that the peripartum period is accompanied by marked changes in circulating thyroid hormone profile that is correlated with lipomobilization predictors.

Key words: dairy cow, metabolism, thyroid hormone, transition period

\section{INTRODUCTION}

The time from late pregnancy to early lactation is known as the transition period and it is recognized as the period between 3 weeks before to 3 weeks after parturition in the ruminant [1-3].

\footnotetext{
*Corresponding author: e-mail: giuseppe.piccione@unime.it
} 
Cows in late gestation have higher metabolic demands and less feed intake compared to cows in the early dry period and enter a period of negative energy balance (NEB) intensified in early lactation when feed intake lags behind milk production $[4,5]$.

Thyroid gland hormonal activity has an important role in the peripartal period for determining the cell metabolism intensity, the metabolism of lipids and carbohydrates, as well as the course of lactation. Thyroid hormones modulate metabolism in ruminants in which carbohydrates and lipids are the major constituents [6]. Transition dairy cows are often characterized by a decrease in serum glucose level and an increase of nonesterified fatty acids (NEFA) and $\beta$-hydroxybutyrate (BHB) serum concentrations, suggesting the difficulty of dairy cows to cope with the energy demand which characterizes the transition period [7].

Concentrations of blood metabolites including BHB, NEFA, glucose and insulin may provide some indication of postpartum disease risk and can be useful as a herd monitoring tool [7-9]. The positive correlation between circulating thyroid hormones concentrations and metabolic variables is well known in many animal species including cattle [10-14]. At the level of the hypothalamus, thyrotropin-releasing hormone is released which stimulates the pituitary to secrete the thyroid-stimulating hormone (thyrotropin or TSH). TSH in turn drives the thyroid gland to release the prohormone thyroxine T4 into the circulation. Conversion of T4 in peripheral tissues produces the active hormone 3,5,3'-tri-iodothyronine (T3) and reverse T3 (rT3) which is thought to be metabolically inactive. Both T3 and T4 are present in the blood circulation, although the physiological effects are attributed almost only to T3 [15-17]. In view of such considerations, the aim of the present study was to evaluate the changes of some biochemical parameters and of serum thyroid hormones including T3, T4 and TSH, as well as their relationship in dairy cows around calving. Moreover, the critical thyroid hormones thresholds based on the critical values of $\mathrm{BHB}$ and NEFA, previously identified as predictors of ketosis, were estimated in order to identify possibly diseased dairy cows.

\section{MATERIALS AND METHODS}

All treatments, housing and animal care were carried out in accordance with the standards recommended by EU Directive 2010/63/EU for animal experiments.

\section{Farm and animals}

Eighty-two multiparous Holstein Frisian cows (Bos taurus) were enrolled from a high production dairy farm in Northeast Italy: 29 cows in the second lactation, 27 in the third lactation and 24 in the fourth lactation. Farm management included a dry period of 60 days and a period of 15 days before calving in which the cows are fed a diet with increased energy density. The chemical composition of the diets used during steaming-up and subsequent early lactation is reported in Table 1. The cows produced an average of $9490.58 \pm 2461.39 \mathrm{~kg}$ milk per lactation, with an average of $3.64 \%$ 
of milk-fat and 3.25\% of milk-protein. All the animals were clinically healthy and free from internal and external parasites. Their health status was evaluated based on rectal temperature, heart rate, respiratory profile, appetite and fecal consistency. Body condition score (BCS) of each cow was evaluated on a scale from 0 to 5 [18] at $5 \pm 3$ $\mathrm{d}$ before and $5 \pm 3 \mathrm{~d}$ after calving.

Table 1. Feed ingredients and chemical composition of the total mixed ratio (TMR) administered in pre-partum and post-partum periods

\begin{tabular}{lcc}
\hline Total mixed ratio (TMR) & Pre-partum & Post-partum \\
\hline Feed basis (kg/animal) & 20.40 & 25.10 \\
\hline Dry Matter (DM) (kg/animal) & 11.74 & 19.86 \\
Dry Matter Intake (DMI) (kg/animal) & 11.14 & 19.60 \\
Chemical composition (\%) & Pre-partum & Post-partum \\
Crude protein & 13.42 & 16.83 \\
Ethereal extract & 4.27 & 5.89 \\
NDF & 41.12 & 30.10 \\
ADF & 25.96 & 20.35 \\
NFC & 34.28 & 38.06 \\
Starch & 14.87 & 27.99 \\
\hline
\end{tabular}

NDF: Neutral Detergent Fiber; ADF: Acid Detergent Fiber; NFC: Non Fiber Carbohydrates

\section{Blood sampling and biochemical analysis}

Blood sampling was performed from each animal at $5 \pm 3 \mathrm{~d}$ pre-partum and $5 \pm 3 \mathrm{~d}$ post-partum. Polyethylene catheters were aseptically inserted into the external jugular vein. Blood samples were collected into $8 \mathrm{~mL}$ serum vacuum tubes (BD Vacutainer Systems, Preanalytical Solutions, Plymouth, UK). The samples were allowed to clot for 30 minutes at room temperature, then the tubes were centrifuged (Labfuge 400, Heraeus) at $1750 \mathrm{~g}$ for 10 minutes and the obtained serum was stored at $-18^{\circ} \mathrm{C}$. Hormonal profile analyses included: triiodothyronine (T3; ng/dL), thyroxine (T4; $\mu \mathrm{g} /$ $\mathrm{dL}$ ) and thyroid-stimulating hormone (TSH; $\mu \mathrm{lU} / \mathrm{mL}$ ). T3, T4, TSH concentration in each sample was quantified by means of IMMULITE ${ }^{\circledR} 2000$ (Siemens) instrument and commercial kits (Immunolite 2000 Total T3/L2KT36; Immunolite 2000 Total T4/L2KT46; Immunolite 2000 Third Generation TSH/L2KTS6; Siemens, Italy). Biochemical analysis included the measurement of NEFA, BHB, glucose, $\mathrm{Ca}, \mathrm{Cl}$, $\mathrm{Mg}, \mathrm{P}, \mathrm{K}, \mathrm{Na}$, aspartate transaminase (AST), alanine transaminase (ALT) and urea concentrations. Biochemical parameters were measured using available commercial kits by means of the automated clinical chemistry analyzer Konelab 60I (Thermo Electron Corporation). Free-insulin concentration in each sample was quantified with a commercial 125I-IRMA kit developed for human samples (BI-Ins IRMA kit; CIS Bio International Ltd.) and previously validated for bovine plasma samples [19]. NEFA concentration was determined by using a colorimetric method, NEFA RX Monza test 
(kit no. FA 115, Randox, Crumlin, UK) while BHB concentration was determined with the RANBUT RX Monza test (kit no. RB 1007, Randox, Crumlin, UK).

\section{Statistical analysis}

One-way analysis of variance (ANOVA) was performed in order to assess statistically significant effects of period (pre-partum vs post-partum) on the investigated parameters. $\mathrm{P}<0.05$ was considered statistically significant.

Pearson's correlation test was applied in order to investigate the relationship among thyroid hormones and biochemical parameters.

Critical values of BHB and NEFA previously identified as predictors of ketosis [8] were used to dichotomize data in 4 models: pre-partum BHB; post-partum BHB; prepartum NEFA; post-partum NEFA.

Data were dichotomized: at pre-partum $\mathrm{BHB}$ values $<0.6 \mathrm{mmol} / \mathrm{L}\left(\mathrm{CL} \_\mathrm{BHB}<0.6\right)$ or $\geq 0.6 \mathrm{mmol} / \mathrm{L}$ (CL_BHB $\geq 0.6$ ); at post-partum $\mathrm{BHB}$ values $<1.1 \mathrm{mmol} / \mathrm{L}$ (CL_BHB $<1.1)$ or $\geq 1.1 \mathrm{mmol} / \mathrm{L}\left(\mathrm{CL} \_\mathrm{BHB} \geq 1.1\right)$; at pre-partum $\mathrm{NEFA}$ values $<0.3 \mathrm{mmol} / \mathrm{L}$ $\left(C L \_N E F A<0.3\right)$ or $\geq 0.3 \mathrm{mmol} / \mathrm{L}\left(\mathrm{CL} \_N E F A \geq 0.3\right)$; at post-partum NEFA values $<0.6 \mathrm{mmol} / \mathrm{L}\left(\mathrm{CL} \_\mathrm{NEFA}<0.6\right.$ ) or $\geq 0 . \mathrm{mmol} / \mathrm{L} \mathrm{NEFA} \geq 0.6$ (CL_NEFA $\geq 0.6$ ).

For each model thyroid hormones were evaluated as predictors of ketosis. Thyroid hormones were evaluated with receiver operator characteristic (ROC) analysis in order to determine critical thresholds for predicting the risk of disease. Data from the preand post-partum cohorts were analyzed separately.

The ROC curves analyze sensitivity (Se) versus 100-specificity (Sp). The point on the ROC curve that has the highest combined Se and Sp was considered the critical threshold. Interpretation of this critical threshold depends on the area under the curve (AUC), such that if AUC $>0.7$ the test is considered accurate [20]. On the basis of ROC analysis we dichotomized data at $<$ or $>$ of critical thresholds and we investigated the effect of hormones levels and time period on the biochemical parameters by means of two-way ANOVA.

Statistical analyses were performed by means of SAS software (version 9.3; SAS Institute, Inc., Cary, NC, USA, 2009).

\section{RESULTS}

Mean values \pm SD of metabolic parameters obtained at the pre-partum and postpartum time points are reported in Table 2. A significant decrease in the levels of thyroid hormones and TSH were found in post-partum cows. Statistical analysis showed lower values for T3 ( $\mathrm{P}<0.01)$, TSH $(\mathrm{P}<0.05)$, T4 $(\mathrm{P}<0.001)$, insulin $(\mathrm{P}<$ $0.01)$, glucose $(\mathrm{P}<0.01)$, ALT $(\mathrm{P}<0.001)$ and urea $(\mathrm{P}<0.05)$ in post-partum than in pre-partum; whereas, higher BHB and NEFA values were found at post-partum than at pre-partum $(\mathrm{P}<0.01)$. No statistically significant effect of the peripartum period was found on the values of blood minerals, with the exception of $\mathrm{K}$ that showed significantly decreased values at post-partum $(\mathrm{P}<0.01)$. Pearson's correlation test results obtained between thyroid hormones and biochemical parameters are shown in Table 3. 
Table 2. Mean values \pm SD of metabolic parameters measured in cows $5 \pm 3$ days pre-partum and $5 \pm 3$ days post-partum periods

\begin{tabular}{|c|c|c|c|}
\hline Parameters & Pre-partum & Post-partum & $\mathrm{p}$ \\
\hline BCS & $3.34 \pm 0.23$ & $2.98 \pm 0.46$ & $* * *$ \\
\hline T3 (nmol/L) & $1.75 \pm 0.27$ & $1.39 \pm 0.34$ & $* *$ \\
\hline TSH (nlU/mL) & $0.032 \pm 0.003$ & $0.012 \pm 0.002$ & $*$ \\
\hline T4 (nmol/L) & $40.93 \pm 11.20$ & $23.38 \pm 6.69$ & $* * *$ \\
\hline $\mathrm{BHB}(\mathrm{mmol} / \mathrm{L})$ & $0.59 \pm 0.12$ & $1.16 \pm 0.36$ & ** \\
\hline NEFA (mmol/L) & $0.24 \pm 0.08$ & $0.86 \pm 0.47$ & ** \\
\hline Insulin (pmol/L) & $28.30 \pm 5.90$ & $11.85 \pm 2.49$ & $* *$ \\
\hline Glucose (mmol/L) & $3.98 \pm 0.91$ & $3.46 \pm 0.95$ & $* *$ \\
\hline $\operatorname{ALT}(\mathrm{U} / \mathrm{L})$ & $18.93 \pm 5.70$ & $16.46 \pm 4.50$ & $* * *$ \\
\hline AST (U/L) & $72.17 \pm 34.10$ & $107.41 \pm 24.40$ & $* *$ \\
\hline Urea (mmol/L) & $9.42 \pm 2.32$ & $7.79 \pm 2.81$ & $*$ \\
\hline $\mathrm{K}(\mathrm{mmol} / \mathrm{L})$ & $4.36 \pm 0.95$ & $3.96 \pm 1.10$ & $* *$ \\
\hline
\end{tabular}

BCS = Body Condition Score; NEFA = Non-Esterified Fatty Acids; BHB = $\beta$-hydroxybutyrate; ALT $=$ Alanine transaminase; AST $=$ Aspartate transaminase

Significances: $* \mathrm{P}<0.05 ; * * \mathrm{P}<0.01 ; * * * \mathrm{P}<0.001$

Table 3. Significant Pearson's correlation results found among thyroidhormones and biochemical parameters

\begin{tabular}{clcc}
\hline Parameters & & $\mathbf{R}$ & $\mathbf{p}$ \\
\hline \multirow{5}{*}{ T3 } & T4 & +0.537 & $* * *$ \\
& TSH & +0.332 & $* * *$ \\
& Glucose & +0.367 & $* * *$ \\
& Insulin & +0.226 & $*$ \\
& NEFA & -0.383 & $* * *$ \\
& BHB & -0.339 & $* * *$ \\
& NEFA & -0.238 & $*$ \\
& Insulin & +0.368 & $* * *$ \\
& Glucose & +0.364 & $* * *$ \\
TSH & Cl & +0.371 & $* * *$ \\
& Mg & +0.344 & $* * *$ \\
& Na & +0.412 & $* * *$ \\
& K & -0.351 & $* * *$ \\
& Insulin & +0.513 & $* * *$ \\
& Glucose & +0.247 & $* *$ \\
\hline \multirow{7}{*}{ T4 } & Mg & +0.330 & $* * *$ \\
& BHB & -0.280 & $* * *$ \\
& NEFA & -0.402 & $* * *$ \\
& AST & -0.304 & $* * *$ \\
\hline
\end{tabular}

NEFA: Non-Esterified Fatty Acids; BHB: $\beta$-hydroxybutyrate; AST: Aspartate transaminase Significances: $* \mathrm{P}<0.05 ; * * \mathrm{P}<0.01 ; * * \mathrm{P}<0.001$ 


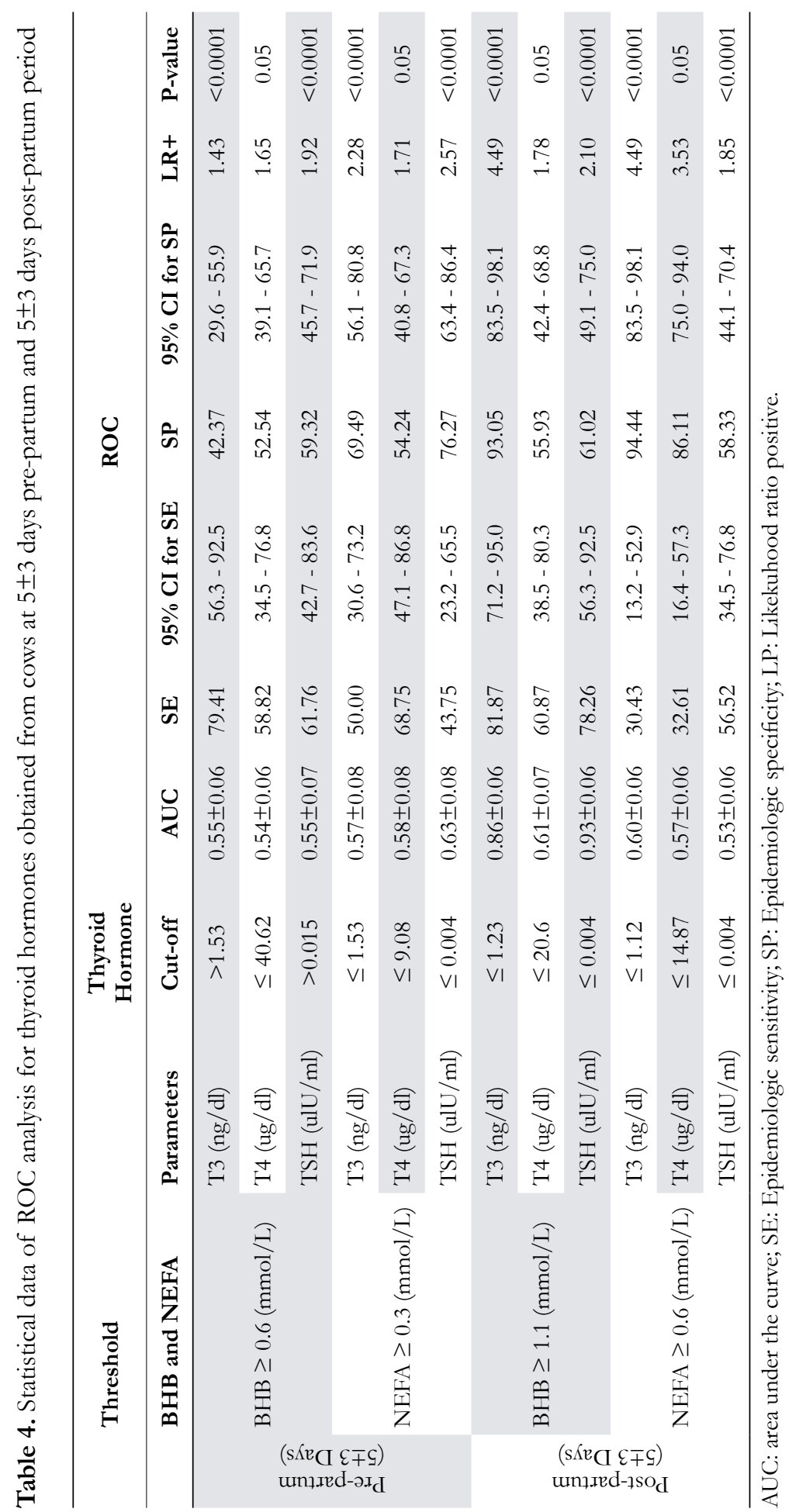


T3 values results positively correlated with T4, TSH, glucose and insulin, and negatively correlated with NEFA and BHB. A significant negative correlation was found between TSH and NEFA values. Moreover, TSH positively correlated with insulin, glucose, $\mathrm{Cl}, \mathrm{Mg}$ and $\mathrm{Na}$. However, a negative correlation between $\mathrm{TSH}$ and $\mathrm{K}$ values was found. T4 positively correlated with insulin, glucose and $\mathrm{Mg}$, and negatively correlated with BHB, NEFA and AST. The optimal cut-off points of thyroid hormones were considered based on ROC curves. As reported in Table 4, ROC analysis suggests that $\mathrm{T} 3$ concentration was a predictive variable at post-partum in the $\mathrm{BHB}$ model. The ROC
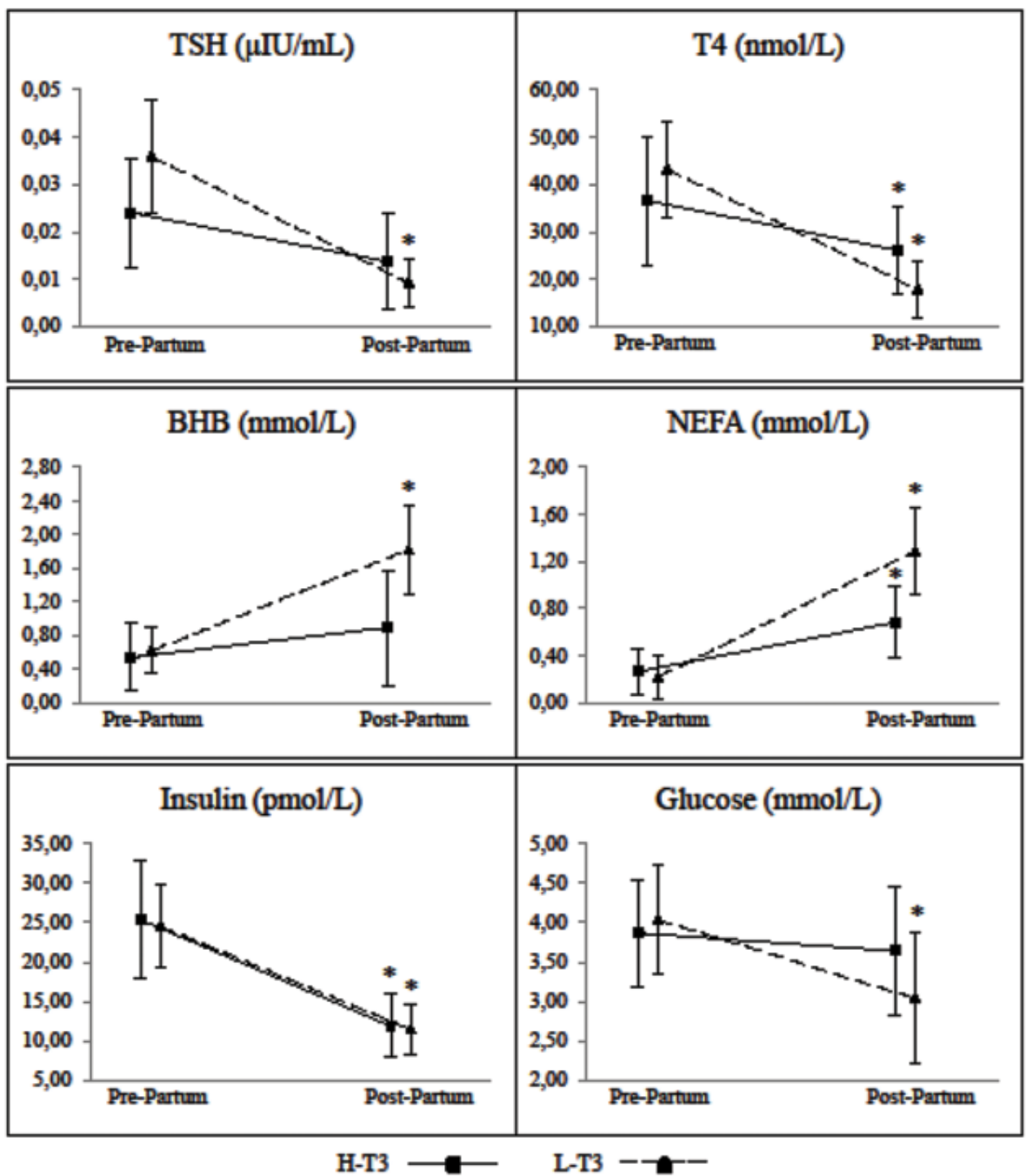

Figure 1. Significant relationships of T3 levels with other metabolic parameters in cows during the monitoring period ( $5 \pm 3$ days pre-partum and $5 \pm 3$ days post-partum ). Animals with T3 $>1.23 \mathrm{nmol} / \mathrm{L}$ are represented as high T3 (H-T3), animals with T3 $<1.23 \mathrm{nmol} / \mathrm{L}$ are represented as low T3 (L-T3)

Significances: * vs Pre-Partum $(\mathrm{P}<0.001)$ 
curve for postpartum T3 showed that AUC was $0.86 \pm 0.06$ and the cut-off value was $1.23 \mathrm{nmol} / \mathrm{L}(\mathrm{Se}=0.81 ; \mathrm{Sp}=0.93)$. Animals with T3 $>1.23 \mathrm{nmol} / \mathrm{L}$ are presented as high T3 (H-T3), animals with T3 $<1.23 \mathrm{nmol} / \mathrm{L}$ are presented as low T3 (L-T3). TSH significantly varied $(\mathrm{P}<0.01)$ in L-T3 but not $\mathrm{H}-\mathrm{T} 3$ animals during post-partum. T4 differed between periods in both groups $(\mathrm{P}<0.001)$. L-T3 was significantly associated with higher values of $\mathrm{BHB}(\mathrm{P}<0.001)$ and NEFA $(\mathrm{P}<0.001)$ in dairy cows during post-partum. Moreover, BHB and NEFA levels in L-T3 animals were higher than in the H-T3 group during post-partum. H-T3 dairy cows showed significantly lower glucose levels at post-partum $(\mathrm{P}<0.001)$; whereas, no effect of the peripartal period was found on glucose values in L-T3 cows (Figure 1).

\section{DISCUSSION}

The hormonal activity of the thyroid gland has an important role for peripartal cows and their offspring in order to determine cell metabolism intensity, metabolism of lipids and carbohydrates, and lactation course. Previous findings reported that cows in postpartum NEB show a decrease in the concentration of T3 and T4 and an increase in the concentration of reverse T3 [21,22]. Our results confirm that the act of parturition in cows is accompanied by marked changes in circulating thyroid hormones with a significant decrease in T3, T4 and TSH levels. The reduction of serum thyroid hormones levels found at post-partum, probably is a reflection of the decreased hormone secretion rate due to energy deficiency, as well as to the large demand for these hormones by the mammary gland [23]. Moreover, the decreased serum concentration of thyroid hormones has been described as an adaptation to NEB [24]. BHB and NEFA are the main blood indicators of ketosis and lipomobilization in ruminants [25,26]. According to Djoković et al. [16], we found negative correlations between serum NEFA concentrations and TSH and thyroid hormones and negative correlations between $\mathrm{BHB}$ and $\mathrm{T} 3$ and $\mathrm{T} 4$.

Serum glucose levels in this study significantly decreased in the post-partum period. However, the mean value remained within the reference range reported for cows (1.9$3.8 \mathrm{mmol} / \mathrm{L})$ [27].

The decrease of glycemia in cows during early lactation may be due to the sudden activity of the mammary gland and increased lactose synthesis. Furthermore, the NEB and lipomobilization in cows affected by ketosis induce a reduction in gluconeogenesis in the liver [16]. Serum insulin values showed to be decreased in the post-partum period, as well. Insulin plays a role in the adaptation of metabolism in dairy cows during the transition period, particularly in terms of nutrient redistribution and partitioning towards the mammary gland during early lactation (insulin resistance) [28]. The decrease in insulin levels found during post-partum is consistent with previous studies which reported high insulin levels before parturition, followed by a gradual decrease from 10 days before parturition remaining relatively low throughout lactation [28]. Lower glucose and insulin levels found during the post-partum period relative to 
the pre-partum period may be due to a decreased responsiveness of pancreatic $\beta$-cells to a state of hyperglycemia, caused by factors which inhibit the release of insulin [7].

Previous studies suggested that thyroid hormones may increase the level of glucose since they increase intestinal absorption of glucose, glycolysis and gluconeogenesis, facilitate glucose uptake by muscles and fat tissues, and increase insulin secretion [30,31]. The post-partum decrease of TSH and thyroid hormones could then be related to insulin resistance leading to a decrease in insulin and glucose levels, as confirmed by the positive correlations found among the three hormones and both insulin and glucose.

Thyroid hormones regulate body hemodynamics, thermoregulation and metabolism. Therefore, these hormones have an influence on renal hemodynamics, glomerular filtration and electrolyte handling. The influence of thyroid hormones on electrolytes seems to be confirmed by the correlations found in the current study among TSH and/or T4 and electrolytes values. In particular, the TSH values resulted positively correlated with $\mathrm{Cl}, \mathrm{Mg}$ and $\mathrm{Na}$ values, and negatively correlated with $\mathrm{K}$. In addition, a positive correlation between T4 and $\mathrm{Mg}$ values was found. The effect of thyroid hormones on electrolytes and minerals has not been well established and also the underlying mechanisms are not well understood [32]. The relationships found among these parameters are probably dependent on the action performed by thyroid hormones on the kidney and other tissues. It has been established that the increase of thyroid hormones leads to serum $\mathrm{Na}$ increase because of the rise of $\mathrm{Na}-\mathrm{H}$ exchanger and $\mathrm{Na}$ Pico-transporter activity first in the proximal tubules then almost in all segments of the nephron [33]. Sodium and potassium are important components of the enzyme $\mathrm{Na}-\mathrm{K}$ ATPase, which is a cell membrane enzyme that helps in the transport of water and nutrients across the cell membrane. Thyroid hormones regulate the activity of sodium potassium pumps in most of the tissues [34].

Critical thresholds of thyroid hormones were determined using the ROC test. Our results indicate that serum T3 values $<1.23 \mathrm{nmol} / \mathrm{L}$ were associated to hyperketonemic cows $(\mathrm{BHB}>1.1 \mathrm{mmol} / \mathrm{L})$ at post-partum. Subsequent analysis of the differences between H-T3 and L-T3 animals highlighted a significant effect of time and T3 levels on BHB, NEFA and glucose values. In animals with low T3 serum concentrations correspond to high levels of BHB and NEFA and a low concentration of glucose. An opposite trend was detected in H-T3 cows. These results could confirm the effect of T3 on liver metabolism as previously described.

The significant variations found in the serum levels of AST, ALT, urea and K, confirm that the transition period represents a critical point in the cow's life since important metabolic changes occur in response to physiological modifications. A similar decrease of urea and $\mathrm{K}$ and the increase of AST levels found at post-partum in this study have been previously described by Fiore et al. [9]. The AST increase could be associated to disorders involving the liver, including ketosis, even at subclinical levels [35]. However, in this study mean values of AST remained within the physiological range reported 
for the cow (78-132 IU/L) [27]. Animals during pre-partum showed higher levels of urea than the reference range of $2.0-7.5 \mathrm{mmol} / \mathrm{L}$ provided by Radostis et al. [27]. Urea decrease in post-partum may be due to low protein intake of periparturient cows [36].

\section{CONCLUSION}

The results obtained in the present study highlight the effect of the transition period on serum thyroid hormones, BHB, NEFA, glucose, insulin, AST, ALT, urea and K concentration in dairy cows. Moreover, a close correlation among studied hormones and biochemical parameters was detected suggesting a relationship between thyroid hormones and predictors of lipomobilization. Monitoring of thyroid hormones, especially T3, could represent an important tool to evaluate the metabolism adaptation in response to $\mathrm{NEB}$ in dairy cows during the peripartum period and in order to understand when regulatory mechanisms break through the physiological limits predisposing the cows to metabolic problems.

\section{Authors' contributions}

All Authors have made substantial contribution to each step of experimental procedure and manuscript preparation. In particular: the idea for the paper was conceived by $\mathrm{EF}$ and MG; the experiments were designed by SG and MM; the experiments were performed by GP and IV; the data were analyzed by BC, TO and FA; the paper was written by EF; the manuscript was critically revises for important intellectual content by MG. All authors have read and approved the final version of manuscript.

\section{Declaration of conflicting interests}

The author(s) declared no potential conflicts of interest with respect to the research, authorship, and/or publication of this article.

\section{REFERENCES}

1. Contreras GA, Sordillo LM: Lipid mobilization and inflammatory responses during the transition period of dairy cows. Comp Immunol Microbiol Infect Dis 2011; 34: 281-289.

2. Morgante M, Gianesella M, Casella S, Stelletta C, Cannizzo C, Giudice E, Piccione G: Response to glucose infusion in pregnant and nonpregnant ewes: changes in plasma glucose and insulin concentrations. Comp Clin Path 2012; 21: 961-965.

3. Fiore E, Piccione G, Perillo L, Barberio A, Manuali E, Morgante M, Gianesella M: Hepatic lipidosis in high-yielding dairy cows during the transition period: haematochemical and histopathological findings. Anim Prod Sci 2015; http://dx.doi.org/10.1071/AN15262.

4. Herdt TH: Ruminant adaptation to negative energy balance. Vet Clin North Am Food Anim Pract 2000; 16: 215-230. 
5. Arfuso F, Fazio F, Levanti M, Rizzo M, Di Pietro S, Giudice E, Piccione G: Lipid and lipoprotein profile changes in dairy cows in response to late pregnancy and the early postpartum period. Arch Tierzucht 2016; 59: 429-434.

6. Huszenicza GY, Kulcsar M, Rudas P: Clinical endocrinology of thyroid gland function in ruminants. Vet Med CZECH 2002; 47: 199-210.

7. Fiore E, Gianesella M, Arfuso F, Giudice E, Piccione G, Lora M, Stefani A, Morgante M: Glucose infusion response on some metabolic parameters in dairy cows during transition period. Archiv Tierz 2014; 57: 1-9.

8. Ospina P.A., Nydam D.V., Stokol T., Overton T.R.: Evaluation of non-esterified fatty acids and beta-hydroxybutyrate in transition dairy cattle in the northeastern United States: Critical thresholds for prediction of clinical diseases. J. Dairy Sci. 2010, 93: 546-554.

9. Fiore E, Barberio A, Morgante M, Rizzo M, Giudice E, Piccione G, Lora M, Gianesella M: Glucose infusion response to some biochemical parameters in dairy cows during the transition period. Anim Sci Pap Rep 2015; 33: 129-136.

10. Kunz PL, Blum JW: Relationships between energy balances and blood levels of hormones and metabolites in dairy cows during late pregnancy and early lactation. J Anim Physiol Anim Nutr 1985; 54: 239-248.

11. Janan J, Rudas P, Bartha T, Bozó S, Gábor GY: Effect of severe energy restriction and refeeding on thyroid hormones in bulls. Acta Vet Hung 1995; 43: 173-177.

12. Leyva-Ocariz H, Lucciola K, Puzzar S: Serum thyroid hormone concentrations during growth and puberty in Carora dairy heifers of Venezuela. Theriogenology 1997; 48: 19-31.

13. Capuco AV, Wood DL, Elsasser TH, Kahl S, Erdman RA, van Tassell CP, Lefcourt A, Piperova LS: Effect of somatotropin on thyroid hormones and cytokines in lactating dairy cows during ad libitum and restricted feed intake. J Dairy Sci 2001; 84: 2430-2439.

14. Cassar-Malek I, Kahl S, Jurie C, Picard C: Influence of feeding level during postweaning growth on circulating concentrations of thyroid hormones and extrathyroidal 5'-deiodination in steers. J Anim Sci 2001; 79: 2679-2687.

15. Leonard JL, Visser TJ: Biochemistry of deiodination. In: Hennemann G (Ed), Thyroid Hormone Metabolism. Marcel Dekker, New York, pp. 189-229, 1986.

16. Djoković R, Cincovic M, Kurcubic V, Petrovic M, Lalovic M, Jasovic B, Stanimirovic Z: Endocrine and metabolic status of dairy cows during transition period. Thai J Vet Med 2014; 44: 59-66.

17. Flier JF, Harris M, Hollenberg AN: Leptin, nutrition and the thyroid: the why, the wherefore, and the wiring. J Clin Invest 2000; 105: 859-861.

18. Edmonson A, Lean I, Weaver L, Farver T, Webster G: A body condition scoring chart for Holstein Dairy Cows. J Dairy Sci 1989; 72: 68-78.

19. Kerestes M, Faigl V, Kulcsár M, Balogh O, Földi J, Fébel H, Chilliard Y, Huszenicza G: Periparturient insulin secretion and whole-body insulin responsiveness in dairy cows showing various forms of ketone pattern with or without puerperal metritis. Domest Anim Endocrinol 2009; 37: 250-261.

20. Swets JA: Measuring the accuracy of diagnostic systems. Science 1988; 240: 1285-1293.

21. McGuire MA, Vicini JL, Bauman DE, Veenhuizen JJ: Insulin-like growth factors and binding proteins in ruminants and their nutritional regulation. J Anim Sci 1991; 70: 29012910.

22. Yambayamba ESK, Price MA, Foxcroft GR: Hormonal status, metabolic changes, and resting metabolic rate in beef heifers undergoing compensatory growth. J Anim Sci 1996; 74: 57-69. 
23. Fiore E, Piccione G, Gianesella M, Praticò V, Vazzana I, Dara S, Morgante M: Serum thyroid hormone evaluation during transition period in dairy cows. Arch Tierzucht 2015; 58: 403-406.

24. Tiiratz T: Thyroxine, triiodothyronine and reverse triiodothyronine concentrations in blood plasma in relation to lactational stage, milk yield, energy and dietary protein intake in Estonian dairy cows. Acta Vet Scand 1997; 38: 339-348.

25. Oetzel GR: Monitoring and testing dairy herds for metabolic disease. Vet Clin North Am Food Anim Pract 2004; 20: 651-674.

26. Gonzalez FD, Muino R, Pereira V, Campos R, Benedito JL: Relationship among blood indicators of lipomobilization and hepatic function during early lactation in highyielding dairy cows. J Vet Sci 2011; 12: 251-255.

27. Radostits OM, Gay CC, Blood DC, Hinchcliff KW: Veterinary Medicine. London, United Kingdom: WB Saunders; 2000, 1618-1690.

28. Balogh O, Szepes O, Kovacs K, Kulcsar M, Reiczigel J, Alcazar JA, Keresztes M, Febel H, Bartyik JGy, Fekete S, Fesus L, Huszenicza GY: Interrelationships of growth hormone Alu I polymorphism, insulin resistance, milk production and reproductive performance in Holstein-Friesian cows. Vet Med CZECH, 2008; 53: 604-616.

29. Butler ST, Marr AL, Pelton SH, Radcliff RP, Lucy MC, Butler WR: Insulin restores GH responsiveness during lactation-induced negative energy balance in dairy cattle: Effects on expression of IGF-I and GH receptor 1A. J Endocrinol 2003; 176: 205-217.

30. Guyton A: Textbook of Medical Physiology, 17th edn. Philadelphia, USA: Saunders; 1986, 897-906, 1061-1068.

31. Cunningham JW: Textbook of Veterinary Physiology, 3rd edn. Philadelphia, USA: Saunders; 2000, 342-346.

32. Mariani LH, Berns JS: The renal manifestations ofthyroid disease. J Am Soc Nephrol 2012; 23(1): 22-26.

33. Schmitt R, Klussmann E, Kahl T, Ellison DH, Bachmann S: Renal expression of sodium transporters and aquaporin-2 in hypothyroid rats. Am J Physiol Renal Physiol 2003; 284(5): F1097-1104.

34. Bharti A, Shrestha S, Rai R, Singh MK: Assessment of serum minerals and electrolytes in thyroid patients. Int J Adv Sci Res 2015; 1(06): 259-263.

35. Meyer DJ, Harvey JW: Evaluation of hepatobiliary system and skeletal muscle and lipid disorders. In: Veterinary Laboratory Medicine. Interpretation and Diagnosis. London, Toronto, Montreal, Sydney, Tokyo: W.B. Saunders Company Philadelphia; 1998, 157-187.

36. Carroll DJ, Barton BA, Anderson GW, Smith RD: Influence of protein intake and feeding strategy on reproductive performance of dairy cows. J Dairy Sci 1988; 71, 3470-3481. 


\section{PROMENE U NIVOIMA TIREOIDNIH HORMONA I METABOLIZMU KOD MUZNIH KRAVA U PERIODU TELENJA}

FIORE Enrico, GIAMBELLUCA Sonia, MORGANTE Massimo, PICCIONE Giuseppe, VAZZANA Irene, CONTIERO Barbara, OREFICE Tiziana, ARFUSO Francesca, GIANESELLA Matte

Hormonska aktivnost tireoideje igra veoma važnu ulogu kod preživara a u cilju modulacije metaboličkih parametara. U studiji obavljena je evaluacija tireoidnih hormona i biohemijskih parametara kod muznih krava u periodu telenja pri čemu je ustanovljen kritičan prag koncentracije tireoidnih hormona u cilju procene rizika nastanka ketoze. Uzorci krvi su sakupljeni od 82 muzne krave u periodu od $5 \pm 3$ dana pre telenja kao i $5 \pm 3$ dana posle partusa. Posle izdvajanja seruma, ispitivane su koncentracije trijodotironina (T3), tiroksina (T4), tiroid-stimulirajućeg hormona (TSH), neesterifikovanih masnih kiselina (NEFA), $\beta$-hidroksibutirata (BHB), insulina, glukoze, $\mathrm{Ca}, \mathrm{Cl}, \mathrm{Mg}, \mathrm{P}, \mathrm{K}$, $\mathrm{Na}$, aspartat transaminase (AST), alanin transaminaze (ALT) kao i uree. U postpartalnom periodu uočen je značajan pad koncentracije T3, T4 i TSH. Vrednosti T3 i T4 su bile u negativnoj korelaciji sa NEFA i BHG koncentracijama a TSH vrednosti su bile u negativnoj korelaciji sa DEFA. Kritični nivoi tj. prag T3 bio je ustanovljen primenom ROC analize a sa ciljem predviđanja rizika od ketoze. Koncentracije T3 ispod $1,23 \mathrm{nmol} / \mathrm{L}$ bile su povezane sa $\mathrm{BHB}>1,10 \mathrm{nmol} / \mathrm{L}$ posle partusa, koje predstavljaju granične $\mathrm{BHB}$ vrednosti koje se uobičajeno koriste kao indikator hiperketonemije. Rezultati ukazuju da je peripartalni period povezan sa značajnim promenama u profilu i koncentracijama tireoidinih hormona u cirkulaciji što može da bude u korelaciji sa predviđanjem mobilizacije masti. 